\title{
Lead Us Not into Translation: Notes Toward a Theoretical Foundation for Asian Studies
}

Comment ne pas se soumettre à la traduction: Propositions de bases théoriques pour les Etudes asiatiques

Michael DUTTON

\section{OpenEdition}

\section{Journals}

Édition électronique

URL : http://journals.openedition.org/transtexts/458

DOI : $10.4000 /$ transtexts. 458

ISSN : 2105-2549

Éditeur

Gregory B. Lee

Référence électronique

Michael DUTTON, «Lead Us Not into Translation: Notes Toward a Theoretical Foundation for Asian Studies », Transtext(e)s Transcultures 跨文本跨文化 [En ligne], 7| 2012, mis en ligne le 02 décembre 2012, consulté le 21 avril 2019. URL : http://journals.openedition.org/transtexts/458 ; DOI : 10.4000/ transtexts.458 


\section{Transtext(e)s}

Transcultures 跨文本跨<smiles>[AlH2]</smiles>

Journal of Global Cultural Studies

7 | 2012 :

Transcultural Identity and Circulation of Imaginaries

Varia

\section{Lead Us Not into Translation: Notes Toward a Theoretical Foundation for Asian Studies}

Comment ne pas se soumettre à la traduction : Propositions de bases théoriques pour les Etudes asiatiques

MiCHAEL DUTTON

\section{Résumés}

English Français

I begin this work with a simple question. Why is it impossible to imagine, much less write, a work like Michel Foucault's Discipline and Punish within Asian area studies? The impossibility I am referring to is not of content but of form. It is not just about writing such a text but about having it read as something more than a description; having it read for its theoretical significance more generally. That is to say, it is about the impossibility of writing a work that is principally of a theoretical nature but that is empirically and geographically grounded in Asia rather than in Europe or America. Why is it that, when it comes to Asian area studies, whenever "theory" is invoked, it is invariably understood to mean "applied theory" and assumed to be of value only insofar as it helps tell the story of the "real" in a more compelling way?

To some extent, what follows is an attempt to explain historically how Western area studies on Asia came to appreciate theory in this limited and limiting way. At the same time, as I began to investigate the history and prehistory of this diaphanous field, I began to recognize the possibilities of a very different form of area studies that could have emerged had different sets of pressures pushed it in a slightly different direction. This essay is therefore an attempt to recuperate these now forgotten possibilities and to build on them in order to produce a different way of seeing, writing, and theorizing Asian area studies. 
Je commence cet article par une simple question. Pourquoi est-il impossible d'imaginer, encore moins d'écrire, une œuvre comme Surveiller et Punir au sein des Etudes asiatiques ? L'impossibilité à laquelle je me réfère n'est pas liée au fond mais à la forme. Il ne s'agit pas seulement d'écrire un tel texte mais de le faire lire comme quelque chose qui soit plus qu'une description ; le faire lire aussi pour sa portée théorique. Il s'agit de l'impossibilité d'écrire une œuvre qui serait de nature essentiellement théorique mais qui, empiriquement et géographiquement, serait basée en Asie plutôt qu'en Europe ou en Amérique. Pourquoi donc la théorie, lorsqu'il s'agit des Etudes asiatiques, est invariablement comprise comme une « théorie appliquée » dont la valeur ajoutée repose sur sa capacité à raconter l'histoire du " réel » d'une manière plus convaincante ?

Dans une certaine mesure, ce qui suit est une tentative pour expliquer historiquement comment, en Occident, les Area studies sur l'Asie en sont venues à comprendre la théorie de cette manière limitée et limitative. En même temps, lorsque j'ai commencé à étudier l'histoire et la préhistoire de ce champ diaphane, j'ai pu apercevoir les possibilités d'une forme très différente d'études régionales qui auraient pu émerger si différents ensembles de pressions l'avait poussée dans une direction légèrement différente. Cet essai est donc une tentative pour récupérer ces possibilités désormais oubliées et construire, sur ces bases, une autre manière de voir, écrire et théoriser les Etudes asiatiques.

\section{Texte intégral}

\section{Tales of Translation}

\section{Story One}

There is a story told today about an event in ancient China where in five hundred archers were said to have been dispatched, on the emperor's express orders, to a coastal location near Hangzhou that was about to be reclaimed by imperial engineers. There, in an event that enabled the commencement of this major project, arrows were fired into the sea to ward off the dragon god. These "opening shots" are, in a contemporary Western recollection of the event, said to be "ceremonial," warning the dragon god not to make (violent) waves. Yet the object of this form of "ceremony" and the "engineering" project that it "celebrated" were, in fact, of equal weight, for both were designed to outwit the dragon god and fend off the tempestuous sea so that the land could be reclaimed for the emperor. The techniques differed-the archer used the bow, the engineer, science and technic (in Georges Bataille's ${ }^{1}$ sense)-but their objects were identical. Yet when this account is retold in our time and in our functionalist logic, it becomes a story of scientific discovery, and the archers' tale is relegated to a "ceremonial space" somewhere on the margins of this main scientific account. For me, while the functionalist analysis is a useful corrective to idealism, there is much more to tell, both in the archer's tale and in its retelling as "ceremonial." [1]

2 How much can we trust the unity imposed by this (positivist) narrative strategy? Surely the instrumentalist (re)telling of the archer's tale as a "ceremonial aside" within an overarching story of a developing technical and scientific proficiency should set off a ripple of doubt. After all, the story of scientific curiosity, technical advance, and careful and exact inquiry into currents, winds, and sea patterns, a tale familiar to any contemporary Western reader, now appears stalked by another (more ominous) figure. The shadow of 
the inexplicable "other" side and "other" logic darkens this figure of ceremony, which threatens to turn the tranquil and familiar waters of "our" comprehensibility into something far more uncertain and incalculable. To "read" sea currents anthropomorphically, as the emperor surely did when he dispatched a team of archers to tame the sea dragon, threatens the exactness of calculation and the economy of science that contemporary positivist accounts of these events promote. It threatens to disrupt the unity of what Bataille ${ }^{2}$ once described as the "homogeneous world"-that is, a world of production, science, technic, and rationality-with the disquieting, inexplicable murmur of "unproductive" excess and transgression that he would come to call "heterogeneity." It is for this reason that, in (re)telling this tale within a story of scientific development, it proves all too tempting to render this heterogeneous event as "nothing more" than the popping of a champagne cork, the smashing of a bottle on the bow of a boat, or the "ceremonial" firing of arrows into the sea. It is convenient to treat this moment as that ceremonial preface that is always already familiar to us and, one may care to add, that thereby comes to count for very little.

3 The reproduction of this event as a mere "ceremonial" aside-a somewhat comical, eccentric interlude before the "main act"-or better still, to retell this heterogeneous tale homogeneously by describing it as the "ideological [ceremonial] kernel" around which an otherwise healthy scientific seed was growing, is not only designed to make us feel we have left the troubled and threatening sea for the security of more solid ground, but also to describe the very basis of the Western scientific method. And it is in the work of Bruno Latour and the retelling of another seaside tale that the most compelling evidence of this point can be found.

\section{Story Two}

4 In the final part of Latour's remarkable account of the development of scientific method, he illustrates his argument about "science in action" by recourse to the narrative technique of allegory. Scientific "action at a distance," in Latour's exemplification, takes place on a faraway island (in the distance), with the visit of a Western boat (action) and the recording techniques, transmissions, and finally incorporation into a Western canon of the captain's notes (science).[2] This parable of science, almost in opposition to its own emphasis on rationality, begins, like most fairy tales, with the dawning of a new day:

5 At dawn, 17 July 1787, Lapérouse, captain of L'Astrolabe, landed at an unknown part of the East Pacific, on an area of land that was called "Segalien" or "Sakhalin" in the older travel books he had brought with him. Was this land a peninsula or an island? He did not know, that is, no one in Versailles at the court of Louis XVI, no one in London, no one in Amsterdam in the headquarters of the West Indies Company, could look at a map of the Pacific Ocean and decide whether the engraved shape of what was called "Sakhalin" was tied to Asia or was separated by a strait. ${ }^{3}$

6 As Latour points out, it was the task of the comte de La Pérouse to solve the riddle of these lands. With notebook in hand and "native" before him, the captain began a process of extraction that culminated in revelations being told 
about this land and the mysteries that surrounded it. La Pérouse's role was not to write down everything his informants told him. His task was to extract from the otherwise "fuzzy, approximate and sometimes ungrounded beliefs of local knowledge" what was deemed to have value as scientific raw material ${ }^{4}$. Having extracted, La Pérouse then compressed. Lengthy tales of gods and legends were "translated" into more "rational" instrumental accounts. The scientific seed was extracted, the information translated, and the detail compressed into a mere diary entry. The lived knowledge of the indigenous informant that had taken years to acquire was noted down in summary form that would require no more than a few hours to write and much less time than that to read. La Pérouse would then move on to other islands, other accounts, other extractions, other compressions,... other translations. The indigenous inhabitants' stories would be told time and time again, but in a translated form they would neither know nor recognize as their own. While they drew maps in the sand for La Pérouse, told him of gods and serpents, and used their version of time-a map was drawn to indicate how far their canoes would take them in one day-to indicate distance, this information, when it found its way back to France and into that elaborate dispersed knowledge machine that was the scientific community, would end up taking on a very different form.

7 There, within this community of scientists, technicians, and planners, all dedicated to making the world manageable, intelligible, and portable, La Pérouse's notes were translated into details that would enhance the "bigger picture" of the world known in the language of Western cartographers as the navigational chart. The islands La Pérouse had "discovered" and the details he had taken from the indigenous inhabitants now reappeared in a translated form as a mark on a map. It is this map that marks the distances traveled not only by La Pérouse's boat, but also by Western scientific mapping.

8 From the earliest Christian T-O maps that placed the holy city of Jerusalem at their heart[3] to the later, more elaborate medieval maps that were like logs of pilgrimages undertaken and wondrous religious sites seen, charts of this European past were largely elaborate ideological mapping exercises ${ }^{5}$. These intricately coded systems, carrying both ideological and geographic meaning, display a European sensibility very different from the one in which La Pérouse's "discoveries" would finally find their home. Sometime between the fifteenth and seventeenth centuries the tour disappeared and the itinerary was put under erasure. The stories of life, travels, and tours were "flattened out" and vanished. No longer a heterogeneous collection of ideologically invested signs, the map became instead the site of a new clustering of knowledge we would come to call interdisciplinary. It would draw on the fields of geometry, navigation, and observational ethnography and "speak" in the table-language of science rather than in a dialect of the pilgrim's tale. Maps became the "proper places in which to exhibit the products of knowledge, [and] form tables of

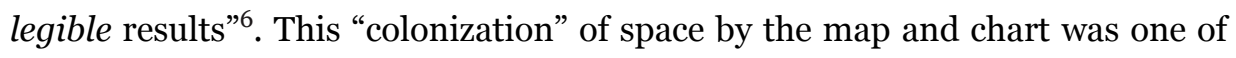
the effects of the birth of science ${ }^{7}$. With science, rather than religion, now being the guiding ethos, the map was transformed into a very different type of instrumentalist "technology." Ultimately, with new additions and clarifications, it would redraw the world along vectors that would make a return journey from Europe to the islands of La Pérouse not only possible, but far more predictable ${ }^{8}$. Extraction, translation, mobility, and an ability to combine with and reconfigure other elements of an existing story; this was the very stuff of 
"science in action."

It is also the "stuff" that ties Latour's vignette of La Pérouse back to the contemporary account of an ancient Chinese "engineering" work. Like the extractive "science work" undertaken by La Pérouse, this contemporary account of ancient Chinese dyke making extracted the "ceremonial" conditions and translated the valued remainder into something that could be combined with other knowledge. It would, by exclusion, define what was deemed the "essential component" of indigenous knowledge. Having removed the dross, it would confidently (re)classify the building of dykes as an "engineering project." Both this story and that of La Pérouse are tales of extraction, translation, mobility, and an ability to combine with and reconfigure other elements of an existing story. They are, methodologically, discrete domains of "science in action," and, as one moves from the natural sciences toward the nascent social sciences and from the end of the eighteenth to the middle of the nineteenth century, one discovers that the buried ideological effects of this "rigorous," "objective," and "scientific" remapping of the world would take another name: imperialism. To excavate this requires moving to my third and final vignette.

\section{Story Three}

At the end of the nineteenth century, in the middle of Paris, the Exposition Universelle opened its gates to the French public and its sights to the public gaze. The world, as Timothy Mitchell ${ }^{9}$ puts it, was thereby enframed. It was rendered, Mussorgsky-like, as a picture at an exhibition, but one that clearly put trade "in the frame." The earlier Crystal Palace exhibition in England offered a stunning example of this. Exhibiting space was granted only on the basis of the value attributed to what one had to sell. It was on this basis, and no other, that nations and space were reordered in a calibrated hierarchy which led to the non-Western world occupying small, marginal corners of the exhibition site: non-Western countries had little of value and therefore little to say in a world ordered around the market and the modern. Indeed, the vast majority of the non-Western exhibits were supplied by European colonialists who treated these lands and their commodities as little short of a joke. Costumes, trinkets, carpets, and hookahs appeared to be the standard array of goods, says C. R. Fay ${ }^{10}$ in his account of Crystal Palace, and these sat somewhat uncomfortably alongside the West's latest technological inventions. Here was a mapping exercise very different from the one that occupied the mind of La Pérouse, but the logic and method behind it were eerily familiar. Extraction, mobility, and an ability to combine with and reconfigure other elements of an existing story was not only the stuff of science in action, but clearly also a central part of imperialism in action.

Like secularized T-O maps of old, these trade fairs reveal an ideological remapping of the world with the West in the center and its agenda on top. In Paris this would be embodied by Gustave Eiffel's tower, the ultimate sign of Western artistic, engineering, and "natural" brilliance.[4] Mimicking the structure of plant life in a manner that would later find full artistic expression in the photography of Karl Blossfeldt, Eiffel created an engineering masterpiece using load-bearing iron girders connected in a manner reminiscent of the common plant. Yet there was nothing "common" about Eiffel's tower. Built for 
the Exposition Universelle and located in the center of the site, it offered an overview of all below and stood as the ultimate sign of Western (and bourgeois) dominance over nature and the world. As if to reinforce this, on the grounds below, and in the shadow of the tower itself, sat another sign of Western dominance, a French-built Egyptian exhibit that reproduced perfectly a winding backstreet scene from Cairo. Such perfect reproduction was confirmation of Western brilliance, not simply because of the architecture of the streetscape but because of the Western technical ability to replicate, in the heart of Paris, the soul of Cairo. Here was a streetscape complete with traditional Egyptian house veneers and the facade of a mosque modeled on the one in Qaitbay. Here was a street scene populated by imported Egyptian donkeys complete with handlers offering rides, Egyptian dancing girls entertaining the passersby, and French traders dressed as Arabs selling trinkets from their bazaar stalls. Even the dirt on the painted buildings was replicated ${ }^{11}$. Old Cairo was transported and in the process transformed. Yet this process of transformation-from lived social form to sideshow-only confirmed the power of the West to extract, replicate, and make anything, anywhere, portable and intelligible in its own terms.

It is with this form of mimesis, where the eye is firmly fixed on transporting things into the homogeneous world, that the logic of the trade exhibition, the diary of La Pérouse, and the contemporary rendition of traditional Chinese engineering meet. It is in these three stories that one confronts the relationship between science, translation, and the epistemic violence of imperialism. The West, it seems, could translate anything. Through the spread of scientific method, texts, buildings, and even life itself were opened to the West's gaze. The tower of Gustave Eiffel became its Babel and the new universal message was that science could conquer all and would make the world whole and wholly intelligible. A new universal language was emerging, not out of the rubble of philology or even out of language proper. Rather, this new universal language was "reason" and its battering ram, capitalism.[5] Capitalism dreamed of flattening the world in the way science had once flattened the monastic pilgrimage maps into navigational charts. Now the desire to trade would flatten difference. Consumption and material desire would point to a new universal language. Materialism would obliterate the dialects of dissent, be they the sacred, the opaque, or the heterogeneous. The homogeneous world would be victorious and, like the colonialists of old, would redraw the map and paint each land in its own colors. If the nineteenth century held out this promise, it is in the twenty-first that we are now being told the promise is being fulfilled. As globalization spreads, it cuts its way through different cultural and lived forms and leads to claims not only about shared desires but also about a shared universal logic of desire. It is in critiquing this logic, a logic now transformed into a more general "style of thought" and sometimes spoken in the "objective" language of the contemporary social sciences, that I want to begin to speak of a dialect of potential dissent offered from within a new type of Asian area studies. It is my contention that, if reconfigured into a domain that speaks to, and of, the occluded heterogeneous world of otherness, Asian area studies has the potential to send ripples of doubt through the dominant positivist social science "stories." 


\section{Bringing the Stories up to Date}

Basing themselves on a (predominantly nineteenth-century) notion of how the "hard" sciences work ${ }^{12}$ these social sciences have produced "applied" models that enlist the now familiar methodology outlined above. Indeed, it is through this methodology that they now lay claim to being objective, rigorous, and scientific. This, of course, involves the eradication or dismissal of unwanted signs of the heterogeneous that cannot be incorporated into the homogeneous world of "their" reason. Nowhere was this process more in evidence than in the ongoing, troubled marriage of comparativist social science modeling and the scholarship that supplied these models with much of their "raw" data on other cultures. As this marriage disintegrates, one begins to notice the social scientific process through which that which cannot easily be incorporated is assimilated, then repressed. Yet, as is clear from the tale of the Chinese dyke builders and their penchant for "ceremony," "the mystery that is incorporated, then, repressed, is never destroyed.... history never effaces what it buries; it always keeps within itself the secret of whatever it encrypts, the secret of its secrets"13. It is in disinterring this "secret of its secrets" that the heterogeneous possibilities of a new area studies of the sign are revealed, and the radical potential of the field made real. But there is much to do before that possibility can be realized.

14 As a geographically defined area of study, rather than a theoretically driven discipline, area studies had long argued that it was interdisciplinary but, as it looked over its shoulder at the "hard" social sciences, it was stalked by the fear that it had no discipline at all. The social sciences had for years made this claim about area studies, and their response, in arguing for a more "area-centric knowledge," only reinforced the suspicion that area studies was indeed a field dominated by descriptive "social translators." Lacking the type of theoretical and "scientific" rigor the disciplines claimed to offer, area studies defined itself only in the shadows of other disciplines and reified its unique quality, translation. But it was this "one thing" that would damn it in the eyes of social scientists.

The most recent and formidable critiques of area studies come from political science, and of those the most vocal is Robert H. Bates.

In a series of articles that damned area studies for lacking the necessary theoretical rigor to rival the social sciences intellectually, Bates called for a new approach that would merely reinforce the already existing role of area studies as subservient subordinate translator. Social science knowledge would be privileged in this arrangement for, unlike the translational practices of the empirically based area study, only it was "equipped to handle area knowledge in a rigorous fashion" 14 . For Bates, at least, the new universal "scientific" techniques deployed by the "rigorous" social scientist were all versions of rational choice theory. With this approach, cultural difference becomes but one variable in a "game" that is constantly reworked to "prove" both the particular argument being proffered and, more important, the universalism of the model being deployed.[6] In fact, all that this model building proved, if proof be needed, was the logocentric nature of the paradigms that dominate the contemporary social science disciplines. The faith of political scientists in both the rationality of political actors and in the objectivity of their theoretical models required only empirical verification. It was at this point that the social 
sciences would require local translators from whom they could gain useful descriptive information that could be reworked into empirical proof of their scientific theories. For the social scientist, the usefulness of the local knowledge supplied by the area studies specialist was therefore also a sign of the theoretical weakness of the field. In many respects, area studies had only itself to blame for this predicament, for it has always, and quite promiscuously, offered itself in this way.

17 Within the subfield or area studies I know best, a line can be traced from the very earliest Jesuit encounters with China through to our day and, despite massive shifts in what and how objects of desire are translated, the model of the area studies scholar as translator remained dominant. Indeed, the one defining characteristic of the sinologist was this ability to translate- both linguistically and culturally. As David Mungello ${ }^{15}$ points out in his examination of some of the earliest European attempts to theorize China and its language, theorists always seemed to have "knowledgeable friends." Gottfried Leibniz had Joachim Bouvet, Athanasius Kircher had Michael Boym, and Christian Mentzal had Philippe Couplet, in much the same way that Julia Kristeva "had" her sinologist-translator, Marcel Garnet. Even when theoretical opportunities did emerge as possibilities for area studies-as happened in recent times when Edward Said rendered the empirical relationship between "Europe and its other" theoretical by describing it as an ontologically and epistemologically charged "style of thought"-they are brought down to earth and employed within area studies as a means to reinforce what could only be described as the "translator's advantage." Paul Cohen ${ }^{16}$, who offered possibly the first detailed response from within Chinese studies to Orientalism, employed this work to authorize his "China-centric approach," which was little more than a critique of theory based on an unreconstructed (and unrealizable) form of empiricism. Why is there such truculent antitheoretical empiricism within area studies? The reasons are manifold but one key reason that has never fully been scrutinized relates to training.

18 Western area studies knowledges are language-based and learning languages has come to operate as a "rite of passage" into Asian area studies for any scholar. Yet it has also, unconsciously, become much more than that; the narrowly defined applied nature of area studies-which lies at the heart of its truculent empiricism-is based on unconscious appropriations from, and a close kinship to, the types of methods employed in language training itself. This methodological kinship between textual and cultural translation is not fortuitous, I would argue, but emerges from a path taken out of the philological tradition by Oriental studies, a path that would become fully developed by the time it was named Asian area studies. What I want to suggest is that the transition from classical philology, of which Oriental studies was a part, into comparative philology, from whence it departed, laid the intellectual ground on which area studies' descriptive and applied translational practices reified an observational method of knowledge acquisition. It is this history that I want to retrace in order to bring forth a repressed alternative of "doing" that could establish the basis for a very different Asian area studies.

Philology, that "empirical science of the spirit" romantically called it, was a nodal point in a discursive field that not only gave birth to linguistics, but also played a key role in the formation of Oriental and later Asian area studies. While it is certainly true that Oriental studies was 
irreducible to philology and philology was much more than Oriental studies, the degree of interpenetration and mutual authorization for works undertaken within these paired fields was nonetheless significant.[7] Oriental studies was crucial to philology insofar as the Oriental languages gave added impetus to the changes within language study, which then moved philology away from its search for a theological origin. The philological tradition was, in turn, pivotal to Oriental studies, because it predisposed the field to a way of seeing that would add a social, political, economic, and cultural dimension to Roman Jakobson' ${ }^{18}$ now famous formulation that anything is translatable. It was this type of formulation that would solidify and stabilize around the methodology of applied language appropriation and translation; for, as is well known, language is the one and only unifying criteria of this field.[8] This would then be reified by the protocols of academic publishing and the utilitarian demands of missionaries, colonialists, governments, and, more recently, business. The "applied" nature of this field came to set the boundaries for what would become an acceptable form of scholarship. In other words, the applied methods of language acquisition shone a light on more general forms of applied knowledge acquisition.

The repetitive, rote learning techniques employed to acquire language inadvertently reinforced a particular understanding of the relationship between "text" and "interpretation," and this would then "solidify" into a mimetically recoded and quite classical binary between "real" and "thought" "slippage" would then produce a set of unconscious understandings that dialectically fed back into the general scholarly program of area studies, producing a tautological justification for the "realist," empiricist, and "applied" approach to knowledge acquisition. The self-evident obviousness and pregiven "realness" of the text became metonymically linked to the pregiven obviousness and realness of "nation" or "culture"; and it was this form of "applied translational practice" that came to constitute the very basis of area studies knowledge.[9] While there are, of course, "stakeholders" (government and business, to name but two) demanding this, the particularly trenchant resistance to theory within this field is not reducible to mere outside pressure groups. The point I want to stress is that there was nothing inevitable about the field's developing in this way. Indeed, a focused reading of its history opens a window onto other ways in which it could have developed and may yet still. Indeed, it is the purpose of this genealogy to highlight just this possibility.

$21 \quad$ I use the term genealogy rather than history quite deliberately. What I have written is not history in the traditional sense. Thus, experts in any of the various subfields that operate under the rubric of Asian area studies, be they China, Japan, or Indic studies, may well fail to see their own subfields' history fully and clearly explored in these pages. That is because the tale I wish to tell is not merely an amalgam of all of the constitutive parts of Asian area studies. In other words, the order of appearance of events, or the relative weight or standing of concerns within any of these subfields, is not merely a version of the area studies field in miniature. Area studies, quite to the contrary, selectively developed some concerns and not others, and the order of appearance of what would become important may not have been reflected equally in all fields. Thus, in research on China the philological urge would remain long after it had faded in other branches of area studies. Similarly, the concerns of colonial governance would fuel an interest in administration and 
observation that would be much less powerful in research on countries that were not colonized. Rather than plot the development of each subdiscipline and explore the way in which they contributed to the development of the field as a whole, I have focused instead on those practices within philology and Oriental studies that would either come to direct the discursive field or to play a pivotal role in the formation of the field. This essay is, therefore, very much a "history of the present," for I am interested in how area studies came to be formed in such a way that its radical potential was neutralized. It is my contention that in employing this genealogical method in a scrutiny of Asian area studies practices and prehistories, the field turned its back on certain possibilities that could have and could yet transform area studies into a more theoretically informed set of intellectual practices. Like the seas that constantly lashed the dykes in Hanzhou, the alternative area studies of which I speak offers the possibility of eroding the shorelines of certainty on which the practices of homogeneous social science incorporation have been built.

By broadening out and theorizing its understanding and appreciation of language study, area studies would come to recognize the theoretically charged nature of any notion of linguistic and cultural difference. Through this recognition, a set of practices could be adopted that not only would help area studies overcome its empiricism, but would also expose the "epistemic violence" of social scientific model building that currently attempts to colonize area studies. A careful examination of the prehistory of area studies not only helps explain why a type of ideologically invested, logocentric, but theoretically informed, translational practice gave way to a descriptive "applied" one, it also helps situate a recuperative move from within the trope of language study itself. After all, the study of language lies behind many of today's most "dissonant" scholarly practices.

From Lacanian psychoanalysis to the structural anthropology of Claude Lévi-Strauss, language formed the basis on which a set of new grammars of understanding came into being. Barthesian semiotic studies also drew on linguistic notions of the signification process to formulate a social semiotics that would reveal a "latent" (connotative) meaning behind the explicit (denotative) one.[10] Like area studies, these three discrete grammars of understanding owe their very existence to philology, but what they would take from this now defunct field was a set of practices very different from those adopted by area studies. And while none of these is without its own problems, they at least share the common virtue of appreciating that "language has not only a grammatical logic but also an historical memory" ${ }^{20}$, and this forces them to explore a world that goes beyond the "manifest" descriptive and empiricist forms that dominate area studies knowledges. They hint at the possibilities available for an alternative "way of doing" language study that is theoretically nuanced, culturally embedded, and speaks directly to the language core of the area study knowledge form.

24 Despite an abiding logocentrism, philology also (and from its very earliest moments) employed a set of buried semiotic practices, which enabled language and knowledge to be tied together in a quest for the truth of the cosmos. They would also infect the early days of Oriental studies and lead the young Victor Hugo to proclaim that "in the century of Louis XIV one was a Hellenist: today one is an Orientalist" ${ }^{21}$. This enchantment with difference underpinned the privileged status Oriental studies once occupied within the Western academy 
and, in a radically different and far less theological way, has reappeared to inform postcolonial discourse as a parallel and possibly rival humanities discourse to area studies social scientism.

To validate the myriad of contentious claims made in these opening remarks requires a detailed examination of philology and a recognition of that field as the precursor to Oriental and Asian studies. Such recognition not only highlights the translational nature of Asian area studies but also helps locate the suggestion that more recent theoretical reflections on translational practices speak directly to issues that should be central considerations within Asian studies. In short, this close examination of the prehistory of Asian area studies raises the specter and possibility of other ways of "doing Asia." To begin to develop this, however, requires a detailed mapping of how the field has become a domain of applied translation, and to tell this tale requires starting, as all good stories do, at the beginning. In this particular case, that beginning is Genesis.

\section{Lead Us Not into Translation}

In the first book of the Bible, we are told how Noah's three sons, Shem, Ham, and Japhet, settled on the plains of Shinar and attempted to build a tower to touch the gates of heaven. We are also told of God's response.

Where once there was one language and one people, God's wrath led to their being scattered and their tongues confounded. Where once "word" and "thing" were one and humankind basked in the wisdom and unity of the "name giver" Adam (who, despite the Fall, was still the most knowledgeable sage the world had known), after Babel, what John Locke later described as "the trick of words" prevailed.[11] Undeterred by God's wrath, later Christian philologists would try to build a new tower and recover this "primitive" transparent language, but they would avoid heresy by building on scripture.

Read literally, the Bible offered a road to redemption and a clue to the recovery of the original transparent language, itself a path back to the wholeness of humankind. Whether one started from the book of the original scribe, Enoch, or from Babel, a reading practice developed that Jacques Derrida $^{22}$ would later describe as the theological prejudice and Hans Aarsleff would call Adamicism, a notion, Aarsleff stressed, that went well beyond the question of "resemblance," for it was too infected by the religious to be reduced to this one notion.[12] The point to note is that, by the sixteenth century, "in becoming Bible-conscious, Europe became Babel-conscious"23.

29 The literal reading of the Bible fueled a scholarly quest for origin that informed the endeavors of archaeologists, philologists, linguists, and theologians alike. It led to studies of arcane language forms that centered on the language of the Bible. If truth were to be found in the revealed nature of Scripture, then the language of Scripture must be the earliest.[13] Hence, under the influence of the Church, scholars of the Renaissance period sought to recover the original primitive language, as early philologists called it, for this language would unlock the oneness of humankind. This early comparative language study involved the comparison of biblical "words," especially verbs or nouns (words of action and naming words) as "signs" that could lead to the (re)discovery of the original primitive language. At the center of this 
teleologically conceived quest was a belief that inscribed in origin was immanent future. Variants on this theme would eventually lead away from the Semitic languages to those that displayed an arcane and distinctive form. Chinese, because of its pictographic characters and ancient lineage, proved to be of particular interest.

30 In this regard, the work of the Jesuit Athanasius Kircher was both idiosyncratic and exemplary. Like many before him, Kircher ascribed central importance to overcoming the "word-thing split," and this, in turn, led him to value highly the pictographic, nonphonetic language forms. He saw a link between Chinese characters and Egyptian hieroglyphics and argued that this pointed to a genealogy of the greatest import ${ }^{24}$. Kircher was not alone in his high valuation of Chinese. John Webb ${ }^{25}$, the first to write in English of the importance of Chinese script, was also the first to posit the idea of Chinese as the "mother tongue" of God. While Origen believed the non-Semitic world had been left to God's angels, Webb suggested they had simply avoided the great flood and, therefore, the wrath of God.[14]

31 Webb's argument highlighted a minor trend in late-seventeenth century scholarship known as the Noachidian theory of descent. In essence, Noachidian theory put forth the idea that Noah's three sons, Shem, Ham, and Japheth, had gone forth and spread God's Law throughout the world, including Asia. According to Leibniz, the prominent German astronomer Johannes Kepler drew on this idea to suggest that the origins of Chinese civilization bore a "remarkable similarity to the Noachide theory" ${ }^{26}$. This theory was, however, greatly challenged because of the reduced role it attributed to the Jews as the chosen people. Clearly, if China was to be so highly valued, the role of the Jews would, by necessity, diminish. That was, of course, until the discoveries at Kaifang.

32 “On May 16, 1707," Maurice Olender ${ }^{27}$ tells us, "Le Journal des Scavans announced to its readers 'a very important discovery' made in K'ai-feng [Kaifang] in the province of Hunan, China." The Jews of China had been discovered and their lineage led back to a time before Christ. From these ancient peoples, it was hoped, an authentic, uncorrupted version of the Bible would be found and Providential truth would be restored. The long simmering controversy over the 1546 decision of the Council of Trent to recognize the Vulgate as the sole authentic biblical text would finally be challenged by this news from the East.

33 Alas, such hopes would not be realized. By 1723, textual research revealed that the Kaifang version of the Bible was virtually identical to the Amsterdam on $^{28}$. Nevertheless, this failed to diminish the belief held by some that within the ancient, sacred, and mysterious scripts of the East an answer to the Western "self" could be found that would prove revelatory. As God was slowly replaced by Mammon, this search for an original language that was itself a search for origin was joined by a newer set of influences emanating from mathematics. The slow emergence of the experimental sciences led to speculation about a new kind of language key that would be based on mechanical and mathematical principles ${ }^{29}$.

34 In crucial respects, this new tendency was itself religiously based insofar as it relied on a methodology employed in the religious exegetical tradition, which searched not for an original language but for "a universal matrix for all languages" ${ }^{\circ}$. That is to say, it sought the universal formula beneath the surface 
of language. The mystical cabalistic techniques of textual decoding offered an example of this religious practice, and they would later play a key role in informing the calculus-based language-generating schemas of Raymond Lull and Nicholas of $\mathrm{Cusa}^{31}$. While such techniques began as a mechanism for the revelation of hidden religious truths and, in Lull's case, offered the possibility of conversion to the universal Truth of Christ, they also led, in part, away from the unity of the Church: like other tendencies abroad at this time, they raised the possibility of challenges to the canonical status of Church readings based on Latin translations.

The principle challenge to Latin, however, came not from language research but from Protestantism, which refused to accept the truth of the canonical Latin translations offered by the Catholic Church. Latin's inability to offer an incontestable textual certainty would lead to its decline. Hence, what was once the universal language of "the known world," held together by sacred commitments was, by the sixteenth century, a language in rapid decline ${ }^{32}$. Increasingly, universality would come not from a shared language of communication but in the form of shared formulas. By 1662, even the Royal Society had abandoned Latin and, within thirty years, the French society did the same. The universal language that had tied Christendom together on the basis of a shared set of linguistic expressions of that religious commitment was no more. In its place there emerged a new linguistic nationalism, on the one hand, and a growing scientific language of universalism, on the other.

Perversely, this decline in Latin led to increased scholarly concern about language, which translated in some quarters into further research on language keys. Through the development of such "keys," it was hoped that any linguistic meaning from whatever language group could be immediately translated, thereby obviating the need for a single universal language ${ }^{33}$. In this respect, the decline of Latin and the rise in interest in language signaled the shift from an old, religiously based form of universality to a new, more abstract one that was being imagined and written in the language of science or pseudoscience. A desire for a new language or a new understanding of language based on logarithmic and algebraic principles was emerging ${ }^{34}$. From Francis Bacon to Robert Boyle, this desire found expression in the various schemes to promote a new, "rational" language; one that would mimic the symbolism of science itself. A new way of seeing was therefore slowly emerging out of old exegetical methods.

37 This shift from the exegetical to the "scientific" signaled, according to Michel de Certeau, a movement from symbol-where hidden textual meanings were interpreted by authorized commentary-to the "cipher"- where analytical techniques offered a "totalizing taxonomy" and "universal instruments" to ensure "comprehensiveness." The "cipher," as de Certeau ${ }^{35}$ notes, was a model that could only come into effect through a homology between erudition and mathematics. Yet while symbol and cipher appear to speak to different worlds, they were not entirely oppositional: both grew from the same desire for God's truth and for linguistic "transparency." Science, therefore, could work in the interests of the one true religion. Unity could once again be restored, but this time it would be proven through the universal truths of science. Indeed, as Renan notes, philology would create the "irrefutable scientific basis for Christianity" and establish a "firm and objective link" between Christian truth and scientific truth ${ }^{36}$. 
Once again, the nonphonetic basis of Chinese proved wondrously portentous. Jesuit linguistic discoveries in China seemed to work in sympathy with scientific innovations in the West to awaken interest in the character-based script of Chinese. At the very time symbolic algebra was forging a new universal community of understandings among scientists, built on shared knowledge of symbols and calculi rather than shared linguistic knowledge, China's character-based language was found to offer an example of these same principles at work within language itself. The religious privilege became a scientific one, as Chinese appeared to be an identikit of what Bacon would call "Real Characters." Chinese, however, was not the only non-Western language to be privileged, nor the only one to undergo a partial revolution in the way that privilege was ascribed.

If the search for the Primitive Language venerated antiquity, then the discovery in 1785 of the ancient Indic script of Sanskrit, which was far older than any Semitic language, would, as Schwab notes, put the final nail in the coffin of a world considered to be only biblical. He argues that this (re)discovery not only upset existent philological theory but, given the early language scholars' insistence on the unity of language and humanity, opened the whole of scholarship to its impact. The problem with this argument is that by the time of Sanskrit's (re)discovery, the old philological argument was a mere shadow of its former self. Even within the religious community the idea of a primitive language had, by this stage, given way to a belief in linguistic diversity before Babel and to the radical idea that linguistic confusion was natural ${ }^{37}$. Moreover, the view of script itself as sacred had long since been eroded, as interest in primitive languages developed into the studies of mother tongues ${ }^{38}$.

40 Nevertheless, even in accepting these important caveats, one should not dismiss Schwab's thesis in toto, for, as even Umberto Eco admits, these theological arguments faded rather than vanished.[15] Moreover, even in faded forms, these old theological arguments unconsciously reinforced the prestige of this ancient language that was now being openly privileged on a very different basis. "All the human sciences," writes Olender ${ }^{39}$, "from history to mythology, and soon to include 'racial science,' were affected by the discovery of a tongue that was known not only as Indo-European but also Aryan." Sanskrit would seal the fate of those old biblically based attempts to forge a close alliance between philology and theology, for the idea of the Semitic languages as origin was no more. At the same time, however, it opened up new intellectual vistas. In this new world of scholarship, the privilege of Sanskrit would derive less from its senescence than from its relationships with European languages. A substantial part of its newly privileged status came from the central place it occupied in Franz Bopp's new field of comparative philology. The importance of Sanskrit to Bopp and other comparative philologists largely rested on the findings of Sir William Jones (as articulated in his 1786 presidential discourse to the Asiatic Society). He was the first to make the now famous correlation between the internal structure of Sanskrit and European language forms ${ }^{40}$. According to Jones, Sanskrit was very close to European languages for it "bears a stronger affinity, both in the roots of verbs and in the forms of grammar, than could possibly have been produced by accident" ${ }^{41}$.

41 Whether one followed Friedrich von Schlegel, who argued that Latin, Greek, and the Germanic and Persian languages were all derived from this "mother 
language," or Bopp, who suggested that Sanskrit was merely the "elder sister," is of little consequence, for the question of the root language had lost its importance ${ }^{42}$. What mattered was Bopp's insistence that Sanskrit exceeded both Greek and Latin in structure and clarity. Hence, he argued that it was of the utmost significance ${ }^{43}$. Sanskrit seemed to possess a dual privilege. It retained its status as a romantic language par excellence, for it opened the Western world to a knowledge of the sacred texts of the East; yet at the same time it played a privileged role in the new "scientific" discourse of comparative grammar. In relation to this, Schlegel's work was critical, and two aspects of his scholarship in particular would come to revolutionize philology and its ways of carrying out research. Indeed, it was on the basis of these two innovations that philology would come to represent itself as the science of language.

First, according to Max Müller, it was Schlegel who came forth with the propositions necessary to undermine the belief in hierarchical classes of languages predicated on age. In place of this, Schlegel suggested smaller language families that were aligned less by ancestry than by shared grammatical structures. Schlegel, in examining the languages of the world, concluded by linking the significant European and classical languages together and then back to Sanskrit. Thus, while the terms "Indo-German" or "IndoEuropean" language group were not his inventions, they were nonetheless an outcome of his work.[16]

43 Second, Schlegel developed the method of "comparative grammar," which provided the theoretical basis for a detailed construction of language families and groups.[17] Comparative grammar offered, for the first time, a systematic means by which to trace language connections and privileges on the seemingly more scientific basis of syntactical structures. Schlegel's comparative grammar displaced the previous emphasis on the word. No longer would one inquire into the essential architecture of the word;[18] instead one would focus on grammatical totality. The effect of this was significant for it broke the connection between language and human activity that had sustained the great philological homology between language and knowledge. With Schlegel's work, philology moved from this classical emphasis on reconciliation of the "word-thing split" toward a more comparative frame where grammar and structure were central to all inquiries. Philology was no longer anchored to references in the Old Testament; it was no longer tied to grand homologies. In place of this, one discovers a more detailed, "rational," but esoteric and introspective study of language structures.

In this transformation one can see the beginnings of the "disciplines," yet at the time the importance of this shift was far from clear. The reasons for this opacity had to do with the dual register by which philology, like Sanskrit, valorized its privileged status. As Aarsleff ${ }^{44}$ has noted, comparative philology had all the hallmarks of a new "model science," but it kept these behind a cloak of "spirituality." Comparative philology maintained the high culture claim to be "opening the sacred books of the East" but now did so on the basis of "rational" scientific methods that enabled it to slide easily into a new world of rational disciplinary divisions. This shift to the more limited disciplinary mode was to have profound effects, not only in terms of the later discipline of linguistics, but also on the overarching field of Oriental studies.

45 "Linguistic finalism" would transform this once theologically inspired search for origins into a more limited but "rational" and "scientific" search for 
knowledge. Hence, the legitimacy of philology was no longer religiously based but dependent on the scientific claims it could make and the "form" of rational argumentation it followed. In terms of the latter, therefore, there were constant attempts by philologists to associate their discipline's methodology with those of the empirical sciences. Schlegel compared comparative philology with Georges Cuvier's comparative anatomy. "Comparative grammar," he wrote, "will give us entirely new information on the genealogy of languages, in exactly the same way in which comparative anatomy has thrown light upon natural history" 45 . The methodology for dissecting language, it seems, was the same as that which ordered and dissected the human body. Methodologically, the science of the living body and the science of the spoken word were kindred spirits. For Müller, the science of geology was a more appropriate analogy,[19] for one could compare rock strata in a quarry in the same way as philologists would compare language grammars. And just as one would dig in a quarry and find ever more ancient layers, so too one could excavate language and discover its past. Yet this search was no longer stoked by those old religious fires that dreamed of bringing to light the unity of languages and peoples. By this time, even when philology looked back to ancient languages, it also looked "inward" to their syntactical structures. The one compensation in all this for the religiously inspired was that this new positivistic approach would offer a more scientific means of translating the truth of Christ into other languages, making possible more Christian conversions. Hence, Müller's suggestion that the development of comparative philology was a shift from the metaphor of Babel to that of the Pentecost was not without a certain materiality!

Where Babel spoke of humanity recovered, the Pentecost spoke of heathens converted. The metaphor of the Pentecost focused on religious salvation, and comparative philology now had a new technical and scientific means to advance this end. Thus, while the proselytizing and evangelical aim of the Church was to save souls, it was, of necessity, built on a bedrock of both colonial conquest and good translational skills. Little wonder that, for Müller, this shift tied the new light of God into the very heart of this new science. For him, philology would be the "technical" means by which the light of Christendom would shine forth upon the heathen. Moreover, it would give birth to a new positivistic social research program in which "old words assumed a new meaning, old problems, a new interest, old sciences a new purpose" 46 . Through this new program all peoples would become susceptible to "the highest mental culture" 47.

47 It is at this point, and with these words, that a crucial factor in the development of Oriental studies begins to reveal itself. "Europe and its other," that intellectual fulcrum generating Oriental studies, reveals its Janus face in this Pentecostal claim and, in a very Schmittian way, even in these early days, shows itself to be political. This desire to convert is the very point at which "faith fights errant faith" and this, as Carl Schmitt so clearly shows, is the most intense of all political moments ${ }^{48}$. As a religious quest, "Europe and its other" carries hidden within itself another potential translation: "friend and enemy."

It is this important religious element in the development of the science of comparative philology-a development that would give birth to both a politics and a field that would eventually, and in a secularized and much more overtly political form, take the name Asian studies-that one would miss if one were to read the account of the development of philology rendered by Foucault in The Order of Things. Strangely, for the author of Power/Knowledge, this element 
of the story and its implications are completely absent.

\section{The Absent Orient of Michel Foucault}

For Foucault, the key element in the episteme that was marked, in part, by the emergence of comparative philology was not the expansion and comparativism of the field, and much less its political implications for the colonial world. What is important for him is the way that the advent of comparative philology announced a particular moment in Western reason when one could no longer speak of language being close to knowledge itself. Instead, as he puts it, a notion of reason came to prevail that would lead language to "fold in upon itself" and reduce it to a mere object of inquiry.[20] Henceforth, studies of language would speak only to the internal architecture of language, and while this was a demotion, this particular demotion had its "compensations" that would trail across an array of fields and leave a mark on the Western mind. One of these "fields of compensation" would speak to the heart and encourage a privileging of the creative language of literature. Another would speak to the head, leading to the "table-language" of those who dreamed of scientific transparency. Still another would speak to a form of reason, the architecture of which was to be found in the syntactical structure of language itself. In all three cases, Foucault traces the shattering effect these "remnants" of the once powerful field of philology would have on the Western notion of reason as they splintered into other domains. There is, however, one splinter that his otherwise expansive account does not trace, and that is the emergence of Oriental studies as a discrete field. This, at first, may seem like Eurocentricism. After all, The Order of Things is organized around the appearance of "Man," and for Foucault, this appearance led to a dramatic rupture with classical forms of knowledge, of which the understandings of language were a central part ${ }^{49}$. It was for this reason that language once again acquired an "enigmatic density" at this time. As we have already seen, such "density" around language was nothing new. What was significant in this new episteme was that this "density" emerged not because of the search for a primary word, but because of the ability of language study itself to create conditions for an epistemic disruption of that cosmology of the word. Indeed, it enabled the creation of a series of metalanguages through which the grammar of Western thought could be questioned. It was the appearance of "otherness" and "dissonance" that, Foucault argues, would come to orientate the critical accent of nineteenth-century thought.

From the grammar of words (Nietzsche), to the grammar of economic life (Marx), and, finally, on to the grammar of those "unspoken phrases" that inhabit our unconscious and speak of our desires and dreams (Freud), Foucault's reading highlights the productive "otherness" of these "disruptive" discourses. Yet the question remains, What of the "disruptive" otherness of languages and cultures of the non-West? They may lack the single, famous "proper name" like Marx, Nietzsche,or Freud through which to summarize their project but, given their disruptive effect on philology itself, surely they, too, are worthy of a "proper place" alongside these disruptive voices of 
European "otherness"? After all, part of their appeal to the nineteenth-century romantics was that their material "otherness" to the culture and logic of Western thought helped define the very notion of European selfhood. Given this, the exploration of the human condition (that is, the emergence of "Man") must surely relate in some ways to the emergence of Oriental studies and help account for its once privileged role.

As I have shown, studies of the Orient and its languages had, in the past and in part, been sutured into the theologically inspired quest for origin. And even after this theological quest for origin was no more, one could still find examples of romantic Oriental scholarship proffering the idea of an exotic yet profound Eastern knowledge that speaks to all of humanity. Oriental studies could still lay claim to a certain gravitas by keeping alive some of these pretensions.

Consider, for example, the fact that many of the romantic writings about the non-West appear, in hindsight, to have been as much a description of certain unconscious preoccupations and repressions about self-prior to the invention of these terms-as they were an exploration of non-Western societies. Could one not posit, for example, that much of the romantic literature discussing the journey of Eastern knowledge was, in part, an empirical metaphor and elucidation of what would now, in a very different "language," be described as the fort-da relation? Could one not also point to the endless mimetic appropriations of Eastern knowledge as one moves from Jules Michelet on individual intuition, Edgar Quinet on liberty, Adam Smith on universal sympathy, and, more explicitly, the Physiocrats on good government?[21] This list of buried signs of significance is, in fact, endless, and if it is, as I have suggested, a key element in the formation of Western knowledge, then this Oriental splinter of philological discourse should have been of the utmost importance to Foucault. After all, the significance of this particular splinter seems to suggest that there could be no discussion of the emergence of "Man" within that domain of knowledge known once as philology without an understanding of the way philology engaged with a domain within its "womb" that spoke of cultures of difference.

The great philologist and Oriental scholar Eugène Burnouf offers an insight into the way this philological prestige and pretense lived on in Oriental studies in this 1823 description of translating a Sanskrit text: "It is more than India, gentlemen, it is a page from the origins of the world, from the primitive history of human species, that we shall attempt to decipher together" ${ }^{50}$. With such a strong romantic confirmation of the importance of this Oriental studies project, albeit one still anchored in origin, the absence of attention to this field in Foucault seems puzzling. Yet, strangely and, almost despite itself, buried within Burnouf's own romantic phrasing lies the answer.

Instead of producing a dissonant new discourse, Burnouf's "decipherment" confirmed the power of an existing one. The methods of textual translation he employed were now utterly dependent on the logic and reasoning of another "language game," namely, science. Here was a "logic" that, ten years hence and in the completely unrelated field of colonial engineering, could reverse Burnouf's high valuation of the East and go on to explain why West was best. It was a reversal summed up in the words of Prosper Enfantin: "Suez is the Centre of our life work. We shall carry out the act for which the world is waiting to proclaim that we are male!" ${ }^{1}$.

On the face of it, Enfantin's assertion of Western male sexuality and 
Burnouf's romantic quest for human origin may appear utterly unrelated. Yet what they shared was a belief in the language, logic, and power that came from different employments of the scientific method. It is this method that locates them both, as Müller puts it, within the "highest mental culture." Extraction, translation, mobility, and an ability to combine with and reconfigure other elements of an existing set of knowledges formed the methodological basis for both these disparate discourses. And just as scientifically based translational practices would render an exact knowledge of texts "from the origins of the world," so, too, the language of modern science, when applied to engineering works, would refashion the ground beneath our feet. The magnetic pull of science was beginning to draw a vast array of "disciplines" into its orbit. Some, as Foucault notes, would develop their own critical accents that would set them apart. Others, however, such as those that were more immediately and directly useful to the process of colonization, would be intellectually reduced, becoming mere foot soldiers of observation. Scientific method, therefore, not only reshaped the ground beneath our feet but also the mental landscape we inhabited. It was at this crucial juncture, a point at which this essay itself returns to its opening theme of "science in action," that Oriental studies would both be born and cursed. In this subtle shift, which actually gave the field its name, Oriental studies would no longer command an alternative possibility of theoretical production but would instead be demoted to the rank of translator and supplier of observations valuable to the work of other (disciplinary) projects. Moreover, all this was taking place at around the time translation studies was reshaping its practices as a result of the magnetic pull of science. Indeed, these epistemic changes would pull even Burnouf's romantic sentiments into the logic of scientific reason and, from there, highlight the one remaining value Oriental studies had, relevance.

\section{Transforming Translation}

56 In classical times, what was essential in translation was not exactitude but expropriation to enrich one's own language. As Saint Jerome put it, "The translator considers thought content a prisoner which he transplants into his own language with the prerogative of a conqueror" 52 . By the middle of the eighteenth century the revolution taking place in comparative philology changed this view.[22] The "original" text was no longer a prison but a laboratory and the conqueror increasingly took on the guise of a scientist of language. While philology had abandoned studies of the word for ones that focused on the structure of language, translation studies rediscovered the importance of the word, albeit in a very different way. With word in hand, it demanded of itself the impossible: a word-for-word translation, or as near as one could get to that.[23] While philology had abandoned the search for origin, translation, in a very different way, reinscribed origin in the privilege it accorded to the (original) text ${ }^{53}$. From the field of comparative philology, with its recently acquired concern for the internal grammars and structures of language, came a translational practice that similarly concerned itself with structure and detail. But the devil in this detail was a turning of the tables on theology's search for truth and transparency in origin. From this time on, translation studies looked forward to a time when the promise of a scientific 
knowledge matrix would fulfill its dream of transparency. Very quickly, however, it became apparent that good translation required more than a word-for-word account. Words required "contextualization," and it was Michel Bréal (in his "Les idées latentes", $1897^{54}$ ) who would state this succinctly: "It does not suffice at all, in order to give an account of a structure of a language, to analyze its grammar and to trace the words back to their etymological values. One must enter into the people's way of thinking and feeling."

It seems clear from this, as Timothy Mitchell intimates, that philology, in part at least, authorized not only the search for the nature of the human spirit but, in the case of knowledges that spoke of material states of being (such as Oriental studies), for a more modest, localized, and applied social research agenda. But why, one might begin to wonder, would this field that required entering "into the people's way of thinking and feeling" approach this as a need for an applied, almost area-studies social research agenda? This question is particularly apposite when one considers those other "splinters" of philological thought that were privileged because of their radically different and quite revolutionary notions of difference. These fields also would need to speak to the question of "the people's way of thinking and feeling," but they would do so not by reference to the surface appearance of things but by focusing instead on the buried processes of signification on which such surfaces were laid. It is at this point that we need to return to Foucault.

58 Foucault points out that the new "grammars" of Marx, Freud, and Nietzsche would build on the "dissonance" buried within Western knowledge of a certain "otherness" of economy, consciousness, and language. If it was indeed from within philology that such dissonance would grow, then religious methods cannot be ignored. This is because these "new grammars" would all, in their own unique ways, gain protean strength thanks to a long held but buried commitment within philology to what we might now call an early "philosophy of the dissonant sign." In classical times, "nouns" and "verbs" would be read beyond their literal meaning as "signs" through which one could trace the language and wonders of God.[24] It was just this attempt to reach beyond the "manifest" level of surface appearance and touch an inner symbolic meaning that would reemerge in a secular form and come to define these new grammars of dissent.

59 Freud's work, for example, would produce a "dissonance" that spoke directly to "the people's way of thinking and feeling" by attempting to unmask the meaning of the "unspoken phrase." In doing this, he would come to recognize the value of past symbolic, religious, and "fanciful" interpretations of dreams but would then pivot this question away from "dream content" operative at a manifest level toward the latent "thought-content" that lay beneath the surface.[25] This approach required the disruption of the order of appearance of phenomena within the dream, and led to an appreciation of compression, substitution as well as concealment. For Freud, such unconscious forms would often manifest themselves in the gesture, the utterance, or the slip of the tongue. They would hint at an unconscious, repressed thought that could be brought to the surface by his "talking cure." Where Freud would look at the internal grammar of the individual in his employment of otherness, Marx, if Slavoj Žižek is to be believed, offered an account of the collective unconscious of capitalism.[26] He would do this by pointing to the way that social change was orchestrated within capitalism under the sign of the "natural laws of 
production." Such natural laws he would reveal as being little more than a form of repression that would enable exploitation to appear "natural." But if the "unconscious" of these "natural laws" could be disinterred, they would be shown to be anything but natural ${ }^{55}$. Even in linguistics, this type of analysis would eventually arise once the inward move of philology was halted by a recognition that language itself was a social phenomenon. Language research would return to social analysis with a recognition that language was a "social event," a "two-sided act," as V. N. Voloshinov ${ }^{56}$ puts it. Thus, far from being internal to itself, language was only explicable in terms of "dialogue."

"Even an infant's cry," writes Voloshinov ${ }^{57}$, "is 'oriented' towards the mother" and the growing recognition of this led away from the philological obsession with reviving "cadavers of written languages." As these "ancient monuments" of the "finished monologic utterance" gave way to a focus on lived verbal utterances ${ }^{58}$, a second shift began to take place. In this post-Saussurian world, emphasis would be redirected to the multitude of ways in which dialogue would be inflected. Stylization, parody, staz, and dialogue were the devices employed by Mikhail Bakhtin when he set about to determine many of the verbal "postures," accents, and subtexts that could transform a remark into a sign of joyousness, anger, interrogation, and so on.[27] In other words, one begins to recognize that the "philosophy of language is the philosophy of the sign"59; herein lay the beginnings of Marxist semiotics.

61 Thus, in altogether different ways (words/signs, conscious/unconscious, economy/political economy), these types of "latent" analyses differed from "manifest" understandings of how one "must enter into the people's way of thinking and feeling."

62 To gain such entry, these "dissonant" discourses employed a kind of internal "otherness" to produce a "distanciation effect" with regard to prevailing knowledge forms, and it was this that created the "otherness" of which Foucault speaks. Yet when it came to the very domain where "otherness" took on a lived material form (Oriental studies), the result was intellectual impoverishment brought on by an applied research agenda that operated almost entirely on a "manifest" level, one reinforced by a view of language itself as only a "tool." In this domain, "the people's way of thinking and feeling" was only registered by surface description and only uncovered at the level of applied, descriptive research using the skills acquired in applied language study.

63 It was this shift of focus away from questions about ontological and theological matters to ones concerned with surface description that led to the "demotion" of Oriental studies from its once privileged place within philology. Moreover, and it was this trajectory that would then form the contours along which area studies' "way of knowing" would eventually travel. The applied, descriptive quality of Asian area studies was, therefore, not simply an effect of Cold War functionalism or a shift from the humanities to the social sciences, although, to be fair, these things would highlight and lay bare the politics behind the sign, "Europe and its other," under which Asian area studies labored. In effect, however, the field had already been theoretically laid out long before it was "named." As Oriental studies was demoted, the field opened itself to an area-studies way of knowing. At the time it looked like anything but a demotion.

One finds that by the late nineteenth century the expansion and 
formalization of colonial governance had put Oriental studies knowledge in great demand. And while this would lead romantics like Schlegel to remark sarcastically that India, with the help of Oriental scholars, had become little more than "England's milch cow" ${ }^{60}$, such critiques were themselves, by this stage, little short of laughable. They mattered little in the face of a field that was both an urgent political necessity and could claim to employ the "scientific method" of the "highest mental culture." Besides, there was also the other undeniable fact that this utilitarian attitude produced the milk of colonial knowledge on which Oriental studies would feed and grow.[28]

While one cannot deny that specific knowledge would be gained through such involvement with government, one should not forget that the most valued form this knowledge would take was always one that could be interpolated into the machinery of colonial government. Here was a display of power/knowledge that, more than anything, demonstrated the "tamed" nature of what could, in theory at least, have been a disruptive domain of knowledge. Intoxicated by its proximity to colonial power and legitimized by its functional use-value, Oriental studies, far from disturbing the grammar of colonial thinking, became utterly complicit with it. Far from "disturbing the words we speak"61, it "translated" those disturbances into words that revealed the "truth" not only of India but, more important, of Western "homogeneous," "scientific" reasoning. Yet the more it reified Western reason as the organizing trope of its understanding of the non-Western world, the more it was forced to accept and employ the "objective" and "rigorous" language of scientific understanding that killed off the possibilities of expressing, even partly, the order of other cosmologies. The more such an understanding offered to governments and missionaries in terms of the functional knowledge value, the more the field split into "functional" subfields that spoke of specific country-based knowledges. As it did this, it further eroded its own status as an independent domain of knowledge that could speak to the essence of things. In heading down this path, Oriental studies not only squandered its potential to speak in its own tongue and produce dissonance within Western reason, but, in exchange for what intellectually, at least, were the meager privileges that would accrue from its status as colonial translator, it opened the door to its own demise at the hands of social sciences, for they would prove to be far more adept at speaking the "objective" language of science. At the time, however, this intellectual demise of Oriental studies appeared to contradict "the facts."

66 Oriental studies emerged as a discrete domain at the very moment when the sciences themselves had begun to value the methodology of "systematic observation" and the so-called empirical style. By the nineteenth century, this methodology was increasingly finding a privileged reception within social inquiry, and the fact that Oriental studies dealt with "real places" and "real things" by employing applied techniques and translations made its empirical observations a model form of applied knowledge. Yet in this claim to its own scientificity Oriental studies would once again begin to falter.

67 By the turn of the nineteenth century, the way descriptive knowledge was viewed had changed dramatically. Earlier statistical analysis had been treated with immense skepticism within the nascent social sciences because of the problem of "like species,"[29] but by the beginning of the twentieth century, this was no longer the case. Francis Galton's work in anthropology, Francis Ysidro Edgeworth's in economics and Karl Pearson's in the philosophy of 
science had begun to produce the type of statistical methodologies that were about to claim their own privileged status as the most "objective" approaches to questions of the social sciences. In effect, this quantitative methodology had already started to erode the more culturally based descriptive approaches at the heart of Oriental studies.[30] As these ideas spread into the social sciences, observational knowledge would no longer be the basis on which a model discipline would be built. Instead, such knowledge would be treated as little more than the raw data awaiting scientific systematization and quantification.

Wedded as it was to observational methods, Oriental studies was quickly becoming little more than a "content provider" for social scientific studies of other cultures. Long gone were the days when Oriental studies was an exalted domain from which one spoke to the essence of things; and squandered were the chances it had of achieving its potential as a site of disruption. Instead, the applied research programs of Oriental studies were increasingly dependent on the theories and scientific practices of other domains of Western knowledge. It was this trajectory that would simultaneously damn this domain intellectually and empower it politically. Thus, while Oriental studies was evacuated of any pretensions to theoretical critique, the one remaining "compensation" offered to this field lay in the claims it could now make to know "native" peoples and languages. Its one distinctive claim thus rested on its applied language training.

Curiously, then, this field that would speak directly to questions of material otherness and difference was never to be theoretically charged or privileged but was instead transformed into a mere domain of application and observation. Thus, while other protégés of philology would achieve exalted status and come to disturb the words we speak and the grammatical habits through which we think (Foucault), the applied nature of Oriental studies found itself increasingly reliant on the language and grammar of science to provide it with a translational key. Lashed firmly to this pole of Western scientific reason, the potentially radical, disruptive, and "heterogeneous" possibilities this field had to offer, if differently conceived, were brought meekly to heel as it became one more brick in the wall around the "homogeneous" world of reason. It was this "style of thought" that would offer Oriental studies its one remaining significant compensation: relevance. And this would go on to define Asian area studies.

\section{Toward an Alternative Conclusion to Asian Studies}

The renunciation by Oriental studies to grand universalizing claims and the birth of a new form of geographically specific knowledge about texts and society -which was later to take the name Asian studies-was brought on by neither a great revolutionary discovery nor a grand methodological shift within the field itself. Instead, the field was slowly transformed as it drew on the social sciences and began to produce work of definite utilitarian value to missionaries and colonial administrators. The increased productivity of translational practices, brought on through the use of new scientific techniques, also furthered this process and reinforced the awe with which scientific method was viewed. In the past, scarce textual evidence had been "supplemented" by individual imagination and creative fancy. With increased translation skills more material 
was rendered into Western languages and this, along with the high value now placed on observation, made imaginative leaps simply unimaginable. Instead of textual scarcity there was now abundance, and this, in turn, increased the tendency to specialize. Where once "the Orient" could be treated as a single object of scholarly inquiry, it was now far too big and complex for such simplicities. As I have already noted, specialized subdisciplines would emerge, and these would cluster around the languages studied. The resulting subfields -sinology, Egyptology, Indic studies, and so forth-reinforced an already existing trend to organize knowledge around country as well as "culture," and this, in turn, furthered the functionality of these fields. Even within these sub-fields, the sheer density of knowledge that was emerging, coupled with the demand by government, business, and a range of other lobbies for this field to produce functional knowledge, meant that they were constantly being pulled into the orbit of various disciplines. These factors in turn reinforced the split between "real" as "place" of description covered by an area study and "thought" as scientific knowledge based in or on a discipline.

Somewhat later, and in the United States, these trends would finally "express" what had long been imminent. By forcing a move away from the humanities and highlighting utilitarian value above all else, what ended up being produced was what one scholar has termed a "North American way of knowing"62. This would clear the field of its remaining romanticism and lead to a combination of language training and training in social science disciplinary skills. By the late twenties the Library of Congress had begun to reorganize its collection into geographically specific domains,[31] and private organizations, such as the Carnegie Institute, were beginning to fund scholarly fieldwork that employed the new "interdisciplinary" social science methodologies in the study of specific non-Western societies. While the projects they funded and endorsed were still based on an examination of past great civilizations, and therefore bore the hallmarks of Oriental studies, the methods being deployed betrayed the now almost complete dominance of the social sciences and offered "telltale signs" of things to come.[32] The arrival of "area studies" would not take long.

These trends would reach their apogee in the changed geopolitical climate that followed the Second World War, but they were already clearly imminent within Oriental studies. Thus, while Ruth Benedict's anthropological study of interned Japanese Americans, commissioned as part of the war effort against Japan, marked one of the first moments of this new field of "applied area studies," it was in fact not a break but the culmination of a long trend. Yet it was also a template of things that followed. Here was a type of scholarship that was contemporary and country based and, most important of all, had immediate policy dividends. Here was a type of scholarship that would inspire an entire generation of utilitarian Cold War area studies scholars. By the late 1940 s the applied models of the social sciences had begun to cast a shadow over the entire intellectual horizon. Increasingly, and much more explicitly than in the past, the new field of area studies would turn to the social sciences for explanations of global developments, for in these, it was hoped, a way would be found to counter the universalizing Marxist revolutionary accounts of development.[33] The politics of the field was now overt, and "friend and enemy" was more than a trope, it policed boundaries of scholarly acceptability. This part of the story of Asian area studies-when area studies becomes an overt weapon of the Cold War-is well-known, as is the later "insurgency" 63 of 
left scholars attached to or associated with the Committee of Concerned Asian Scholars.[34] The overt politicization of this field is not what concerns me here. What does is the limited and limiting notion of what area studies can do intellectually. And that, I have argued, was a battle that was lost even before the invention of area studies knowledges.

73 With language as its only definable core-and, even here, the employment of language only as a domain to train in "application"-it is little wonder that the field now lacks any sense of its own intellectual identity. Yet, as is clear from other domains, language offers a range of other more intellectually exciting possibilities. To break the atheoretical cycle of area studies, yet recognize its core, therefore requires circling back to that moment of language "dissonance" that Foucault identified. It necessitates turning away from the temptation to regard itself only as a content provider for the disciplines and to take more seriously and develop theoretically the study of its core, language. This time, however, language study would not be undertaken purely in order to improve "fluency" or simply for "application" but in order to create a means of producing intellectual "dissonance." It would become a means by which we could start to take cultural difference and the signs of such difference seriously. To do this, we need to return to those moments when philology gave birth to the language of dissent and realize that the moves that enabled Freud, Marx, and Nietzsche to speak in dissonance are historically and intellectually also a possibility for area studies.

To arrive back at that moment, to treat it not historically as the moment when Oriental studies began its slippage into area studies, but theoretically, as a moment of decision about which knowledge form this nascent domain should take, brings us back to the question of language theoretically. Here, the trajectory for the study of language is quite different from the training role it is currently ascribed. Here, it departs from these strictures to suggest a social semiotics that would begin to highlight the connotative possibilities inherent in language itself. Here is one way to unearth latent meaning and heterogeneous forms. It is a means of translating that can give voice to the murmurs of other cosmologies. Perhaps this way the Chinese dyke builders will have their day, not as part of the scientific world of incorporation but as a tale of otherness, difference, and dissent that lets us call into question the epistemic violence of scientific incorporation.

\section{Annexe}

\section{Endnotes}

I would like to thank the Australian Research Council for funding this research and the Max Planck Institute for History in Göttingen, Germany, where I revised this piece during a month-long sabbatical.

[1]. I first took notice of this story when I heard it as an aside in a talk by a prominent historian of Chinese science, who was explaining the sophistication of Chinese dyke-making techniques. The story of ceremony was very much given as light relief, and when the account of the dykes was published, the story of the archers was omitted. It is still, however, very much in the consciousness of the people of Zhejiang. In a recent commentary on the topic, Ye Bingnan retells the story of King Qian and the shooting of 
arrows. King Qian was head of a small state in the five dynasties period, which lasted from 825 to 932 a.d. Ye's ${ }^{64}$ commentary is as follows:

Concerning Qian's repairs of the seawalls to prevent calamities during the Yangtze River tide, there is a folk tale about "King Qian shooting the waves" [钱王射潮]. The story of Qian comes to us from a portrayal in the "Record of the Shooting of the Tides" [射潮记], written by Qian's third generation offspring, Sun Qian Weiyan. It is said of the early days of establishing the dyke that it took place in the eighth month, at a time of high tides and seasonal flooding. The raging tide and pounding swirl made it impossible to carry out construction work. Qian therefore ordered and led the deployment of soldiers to the site. From the hillsides down to the southern side of the mountain sturdy bamboo trees were made into three thousand arrows by woodworkers. These arrows were then adorned with the feathers of various birds, and painted with a fiery red coloration, and newly fired metal was used to make the arrow tips. Five hundred soldiers who had the skill and strength to fire the crossbow were assembled at the banks of the Yangtze River and each archer was given six arrows. Each time there was a tidal rush, they would fire one arrow into the raging torrent. It was in this way that, after they had fired five times, they unexpectedly forced the tide to turn away from Hangzhou Bay and they made these eastern tides turn toward the western hills. It is said of these five hundred archers that they are all buried together at Pubing [浦兵], an area between Houchaomen and Tongjiangmen. Above the ground in which they lay, a memorial was erected to them in a place called Tiezhuangpu. In Hangzhou's Jianggan district; even to this day, there are still two lane-ways bearing the names "the horizontal arrow lane-way" [横箭道巷] and the "vertical arrow lane-way" [直箭道巷]. It is said that these names are related to the story of King Qian and the shooting of the tide.

[2]. For a very different "take" on a similar event, see Michel de Certeau's opening lines in The Writing of History. De Certeau begins this work by examining the etching by Jan van der Straet of Amerigo Vespucci's "discovery" of native Americans (they were not known before?) in the New World. It is with this encounter with the other that de Certeau begins his examination of Western writing as historical practice ${ }^{65}$.

[3]. T-O maps were popular in Christendom from about the seventh to ninth centuries until the mid-130os. They were highly symbolic, being circular in shape and dividing the world into three parts to form a T, at whose center was the holy city of Jerusalem.

[4]. After its erection the artists objected: "We come, writers, painters, sculpters, architects...in the name of French art and history that are both threatened, to protest against the erection in the very heart of our capital of the needless and monstrous Eiffel Tower" (Louis Chéronnet ${ }^{66}$ ). Guy de Maupassant, claims Roland Barthes ${ }^{67}$, "often lunched at the restaurant in the tower, though he didn't much care for the food: 'It's the only place in Paris,' he used to say, 'where I don't have to see it." Despite these early artistic objections to the structural aesthetics of the tower, it was later hailed because it offered "the fundamental aesthetic experience of today's buildings"68. As Walter Benjamin elsewhere said, it was an "incomparable" monument to the "heroic age of technology"69. Susan Buck-Morss notes that Benjamin believed that the artists, in attempting to defend themselves against the perceived threat of this new technology, missed the real danger, namely, the shopwindow where the display of art was "in the service of the salesman"70.

[5]. Indeed, according to Umberto $\mathrm{Eco}^{71}$, one motive for the English search for a universal language key was that it would facilitate trade.

[6]. Little wonder that two of the most famous critics of rational choice theory from within that logic, David Green and Ian Shapiro, have pointed out that the only reason such modeling could be regarded as rigorous and universally applicable was because the models could never actually be falsified! All rational choice does, they claim, is reconfigure existing empirical knowledge into rational choice forms. For that reason, they conclude that rational choice theory has contributed "virtually nothing to the empirical study of politics" 72 . For an excellent and succinct summary of the debate see Brogan $^{73}$.

[7]. Recent German scholarship on China challenges the philological roots of Chinese studies. For my argument, however, the veracity of this history is not the issue. Rather, I am interested in the effects of the belief in this past, irrespective of whether it is a post factum rationalization or not. For the controversial argument suggesting that German Chinese studies is not philological, see Leutner ${ }^{74}$ (thanks to Peter Mereker for guiding me through this). 
[8]. Pierre Ryckmans (Simon Leys) ${ }^{75}$, for example, has argued that "the sinological field is defined linguistically." More recently, Vicente L. Rafael ${ }^{76}$ has defined the whole of area studies as "ensembles of knowledges and practices grounded on specific linguistic competencies and formulated within, as well as across, disciplinary boundaries.”

[9]. In the case of Chinese studies, at least, this was reinforced by the gaozhen (or K'aocheng) approach to knowledge that emerged in the late Qing dynasty and stressed "facts" and philology. See Elman77.

[10]. Barthes's famous example of denotative meaning-"Here's a black soldier saluting the French flag"-was deepened with a recognition of its "symbolic" connotative intent, which in this case suggested a mixture of colonialist nationalism and militarism. For an investigation of this linguistic link see Coward and Ellis ${ }^{78}$.

[11]. Note, for instance, Luther's remark on Adam: "What an ocean of knowledge and wisdom there was in this one man!" See Aarsleff79.

For Locke, of course, such a "trick" was unavoidable, and my use of the term here is therefore ironic. Locke saw words as signs of ideas and language itself as a human invention. Words had no core that tied them back to objects any more than languages were divinely inspired. The whole idea of a search for an original universal language was, therefore, for Locke, a complete misunderstanding of the nature of words and language. For more details on Locke see Aarsleff ${ }^{80}$.

[12]. While some have regarded Enoch as "the scribe" and therefore become interested in the language in which he wrote, Augustine believed that Enoch, the seventh generation from Adam, was simply too ancient to be a reliable witness, and that his book therefore could not be included in the ecclesiastical canon, for false things may have been inserted in it. I wish to thank Allen Kerkeslager (Department of Theology, St. Josephs University, Philadelphia) for his help in positioning Enoch in this debate.

Aarsleff ${ }^{81}$ offers this comment on Adamicism in relation to Foucault's reading in the Order of Things, which he finds too simplistic and secular. Louis Marin ${ }^{82}$ similarly critiques the lack of the religious in that work.

[13]. Hebrew was central to this quest, as the early fathers of the Church attest. Saint Jerome, in one of his epistles to Damascus, wrote that "the whole of antiquity affirms that Hebrew, in which the Old Testament was written, was the beginning of human speech"83. Origen, in his eleventh homily on the Book of Numbers, expresses his belief that Hebrew, originally given by Adam, remained in that part of the world which was the chosen portion of God, rather than being left, like the rest of the world, to one of his angels. For further details and claims to this effect see Müller ${ }^{84}$.

[14]. Webb's words were as follows: "Scripture Teacheth, that the whole Earth was of one Language until the Conspiracy at Babel; History informs us that China was peopled, whilst the Earth was so of one Language, and before that Conspiracy. Scripture teacheth that the Judgment of Confusion of Tongues, fell upon those only that were at Babel; History informs, that the Chinois being fully settled before, were not there: And moreover that the same Language and Characters which long preceding that confusion they used, are in use with them at this very Day." 85

[15]. So diverse was the philological community that even in 1804 the Manchester Philological Society was able to exclude from its membership anyone who spoke of Sanskrit or Indo-European languages and doubted the divine revelations. Moreover, it was not until 1866 that the Société de Linguistique of Paris stopped accepting communication on the question of a universal language ${ }^{86}$.

[16]. See Müller ${ }^{87}$ for the substantive point. It should be noted, however, that while Müller attributes the terms Indo-German and Indo-European to Schlegel ${ }^{88}$, the former term is more readily identified with $\mathrm{J}$. von Klaproth, while the latter is attributed to T. Young.

[17]. While Schlegel's work inspired the new comparativism, it was Francis Bopp who published the first detailed comparative text in 1816. See Müller ${ }^{89}$.

[18]. Or, at the very least, when an emphasis on the word did return, as it would in V. N. Voloshinov's post-Saussurian “dialogical” approach, it would take Leibniz's idea of a "universal grammar" in a very different direction. No longer interested in etymological paths back to God, Voloshinov "demotes" the word to being merely the "purest," most universal and "neutral" of "signs" within any verbal process of communication. With a focus on the signification processes, rather than on the origin of words, Voloshinov 90 revalorizes the word but does so on a new basis: "The entire reality of the word is wholly 
absorbed in its function of being a sign," he stated, thereby offering what would become the beginnings of a Marxist semiology.

[19]. Müller'1 made his view on this point quite clear: "I believe there is no science from which we, the students of language, may learn more than from Geology. Now, in Geology, if we have once acquired a general knowledge of the successive strata that form the crust of the earth and of the faunas and floras present or absent in each, nothing is so instructive as the minute exploration of a quarry close at hand, of a cave or a mine, in order to see things with our own eyes, to handle them, and to learn how every pebble that we pick up points a lesson of the widest range. I believe the same is true of the science of language."

[20]. Foucault ${ }^{92}$. His reading of the effects of comparative philology is found in the chapter "Labor, Life, Language," and it is here that one will find the specific references to which I refer.

\section{[21]. For signposts to these appropriations see Schwab93; and Maverick ${ }^{94}$.}

[22]. The history of translation is long and complex and varies from one country to another. Briefly, within English translation studies at least two different positions prevailed. From the seventeenth century one notes the rise of "transparency" and fluency (or what Lawrence Venuti labels "domestication") as considerations in translation. The other approach is much more literal, that is to say, it retains a certain textual fidelity that produced awkwardness and a certain foreignness in the text translated. For more details on this debate see Venuti95.

[23]. One sees the contemporary effects of this translational method in the defense mounted by area studies against "alien" Western theory. Note for instance, the argument proffered by Paul Cohen ${ }^{96}$ for a China-centric approach:

[The] China-centred approach is intended to delineate an approach to recent Chinese history that strives to understand what is happening in that history in terms that are as free as possible of imported criteria of significance....

...it will be countered, as long as the practitioners of China-centred historiography are Americans, no matter how hard we try to get "inside" Chinese history, we will still end up insinuating into this history vocabulary and concepts that are American. Outsiders can never really develop an insider perspective.... This is true-up to a point.

[24]. Even ostensibly secular readings of grammar, such as those offered by the Port-Royal logicians in the seventeenth century, when more closely scrutinized, turned out to be thoroughly imbued with Christian metaphoricity. As Marin 97 points out, the eucharistic model reveals "the profound coherence of the network of examples illustrating the semiotic theory of Port-Royal." Here is a theory of speech that "simultaneously" develops "a linguistic theology of the Eucharist."

[25]. While recognizing the limitations of past (largely biblical) interpretations of dreams, Freud was still quite clear about their value. In examining the dream books of old he stated that they should not be dismissed in their entirety, for they offer an example of "one of those not infrequent cases where ancient and stubbornly retained popular belief seems to have come nearer to the truth of the matter than the opinion of modern science" 98 .

[26]. Žižek ${ }^{99}$ goes so far as to suggest that there is a "fundamental homology between the interpretative procedure of Marx and Freud-more precisely, between their analysis of commodity and of dreams."

[27]. Skaz is a Russian expression with no English equivalent that is probably best described as "narration with marked speech-event features." See Titunik ${ }^{100} 1973,191 \mathrm{n}$. 19. Here, of course, I am merely rehearsing the "dialogistic" thinking of Mikhail Bakhtin and repeating the point about the "utterance" he makes most forcefully in Baxtin ${ }^{101}$. It should be noted that this point also plays a key role in that classic Bahktin text on language, enigmatically authored by either a close follower or by Bakhtin himself under the alter ego identity of V. N. Voloshinov ${ }^{102}$. See especially part 2, chapters 2 and 3, of the Voloshinov text.

[28]. Who could forget, after all, that the first Western school for the study of Sanskrit was opened by the British East India Company in Hailsbury College in 1805, or that Warren Hastings's plan of 1772 for better governance in Bengal ended up turning on the teaching of Sanskrit as a means to establish a pure "Hindu law." For further details on this see $\mathrm{Cohn}^{103}$. 
[29]. Note Stephen Stigler's ${ }^{104}$ words on the problem of like-species within statistical analysis: "Even as late as 1869 it was necessary for the economist William Stanley Jevons to defend his employment of statistics against the charges that he was wrong to combine prices of several very different commodities into one index in a study of variation in the value of gold."

[30]. On this importance of science as a "trope" see Latour ${ }^{105}$. On the rather slow spread of the statistical method to the social sciences see Stigler ${ }^{106}$.

[31]. In 1928 the Chinese-language books in the Library of Congress were the first holdings to be gathered together and housed in the newly constituted "Division of Chinese Literature," and this would be the model used to reorganize all other Asian language holdings. The Japanese collection would be rearranged sometime after 1930, and in 1938 the Indian collection would begin to be housed in a separate section that became, after 1942, the Indic Studies section of the library's Asian Division. See Library of Congress ${ }^{107}$. Thanks to Mi Chu of the Library of Congress for pointing out to me this process of library rearrangement.

[32]. Dipesh Chakrabarty notes that the first such program undertaken under the auspices of the Social Science Research Council (SSRC) was a study of Mayan culture, which brought together archaeologists, ethnologists, historians, geographers, biologists, nutritionists, medical research workers, and other types of specialists; Chakarabarty ${ }^{108}$; citing Stewart ${ }^{109}$.

[33]. For examples of this in relation to China see Barlow ${ }^{110}$.

[34]. So one finds that in the postwar era in Chinese studies (like many other non-Western areas) the struggle was said to have taken place between the modernization "paradigm" and a more revolutionary outlook. For a critique of what in some respects foreshadows Cohen's work arguing for a China-centric approach, see Myers and Metzer ${ }^{111}$. For a critique that argues for the need for greater (not lesser) theoretical rigor, see Johnson ${ }^{112}$; yet even here, while theoretical rigor is said to be needed to sharpen our focus, what is meant by theory is little more than stronger reading glasses for the social translator.

\section{Notes}

1 Georges Bataille, “The Psychological Structure of Fascism”, New German Critique, $\mathrm{n}^{\circ} 16,1979$, pp. 64-87.

2 Ibid., p. 65.

3 Bruno Latour, Science in Action, London, Open University Press, 1987, p. 215.

4 Ibid., p. 216.

5 Walter D. Mignolo, "Misunderstanding and Colonization: The Reconfiguration of Memory and Space”, South Atlantic Quarterly, n 92, 1993, pp. 221-222.

6 Michel de Certeau, The Practice of Everyday Life, translated by Steven Rendall, Berkeley, University of California Press, 1984, p. 121.

7 Ibid., p. 120.

8 Bruno Latour, Science in Action, London, Open University Press, 1987, p. 221.

9 Timothy Mitchell, Colonizing Egypt, New York, Cambridge University Press, 1988, p. 6.

10 C. R. Fay, Palace of Industry, Cambridge, Cambridge University Press, 1951, p. 88.

11 Timothy Mitchell, Colonizing Egypt, New York, Cambridge University Press, 1988, p. 1.

12 Bruce Cumings, "Seeing Like an Area Specialist", in Masao Miyoshi and Harry Harootunian (dir.), Learning Places: Area Studies, Colonial, Cultural, Ethnic Studies, and Received Disciplines, Durham, NC, Duke University Press, 2002.

13 Jacques Derrida, The Gift of Death, translated by David Wills, Chicago, University of Chicago Press, 1995, p. 21.

14 Robert H. Bates, "Letter from the President: Area Studies and the Discipline", APSA-CP (newsletter of the APSA Organized Section in Comparative Politics), $\mathrm{n}^{\circ} 7.1$, 
1996, p. 2.

15 David E. Mungello, Curious Land: Jesuit Accommodation and the Origins of Sinology, Stuttgart, Franz Steiner, 1985, p. 135.

16 Paul Cohen, Discovering History in China,New York, Columbia University Press, 1984 .

17 Maurice Olender, The Languages of Paradise: Race, Religion, and Philology in the Nineteenth Century, translated by Arthur Goldhammer, Cambridge, Harvard University Press, 1992, p. 52.

18 Roman Jakobson, "On Linguistic Aspects of Translation", in Schulte and Biguenet (dir.), Theories of Translation: An Anthology of Essays from Dryden to Derrida, 1992.

19 Tejaswini Niranjana, Siting Translation, Berkeley, University of California Press, 1992.

20 Walter D. Mignolo and Freya Schiwy, "Translation/Transculturation and the Colonial Difference", in Elizabeth Boyi, Beyond Dichotomies, Syracuse, NY, Syracuse University Press, 2001.

21 Raymond Schwab, The Oriental Renaissance: Europe's Rediscovery of India and the East, 1680-1880, translated by Gene Patterson-Black and Victor Reinking, New York, Columbia University Press, 1986, p. 15.

22 Jacques Derrida, Of Grammatology, translated by Gayatri Spivak, Baltimore, MD, Johns Hopkins University Press, 1974, p. 75.

23 Fredrick Bodmer, The Loom of Language. London, George Allen and Unwin, 1944, p. 444 .

24 David E. Mungello, Curious Land: Jesuit Accommodation and the Origins of Sinology, Stuttgart, Franz Steiner, 1985, pp. 134-164.

25 John Webb, An Historical Essay Endeavouring a Probability That the Language of the Empire of China Is the Primitive Language, London, Printed for N. Brook, 1669.

26 David E. Mungello, Curious Land: Jesuit Accommodation and the Origins of Sinology, Stuttgart, Franz Steiner, 1985, p. 35.

27 Maurice Olender, The Languages of Paradise: Race, Religion, and Philology in the Nineteenth Century, translated by Arthur Goldhammer, Cambridge, Harvard University Press, 1992, p. 21.

28 Ibid., p. 22.

29 David E. Mungello, Curious Land: Jesuit Accommodation and the Origins of Sinology, Stuttgart, Franz Steiner, 1985, p. 39.

30 Umberto Eco, The Search for the Perfect Language, translated by James Fentress, Oxford, Blackwell, 1995, p. 49.

31 Ibid., p. 60 and p. 69.

32 Benedict Anderson, Imagined Communities: Reflections on the Origin and Spread of Nationalism, London, Verso, 1983, pp. 24-25.

33 Ibid., p. 194.

34 Fredrick Bodmer, The Loom of Language, London, George Allen and Unwin, 1944, pp. 443-444.

35 Michel de Certeau, The Writing of History, translated by Tom Conley, New York, Columbia University Press, 1988, p. 74.

36 Maurice Olender, The Languages of Paradise: Race, Religion, and Philology in the Nineteenth Century, translated by Arthur Goldhammer, Cambridge, Harvard University Press, 1992, p. 77.

37 Umberto Eco, The Search for the Perfect Language, Translated by James Fentress, Oxford, Blackwell, 1995, p. 86.

38 Ibid., p. 85.

39 Maurice Olender, Ibid., p. 7.

40 Ferdinand de Saussure, Course in General Linguistics, translated by Wade Baskin, London, Peter Owen, 1959, p. 2. 
41 Holger Pedersen, The Discovery of Language, Bloomington, Indiana University Press, 1931, p. 18.

42 Michel Foucault, The Order of Things: An Archaeology of the Human Sciences,New York, Vintage, 1970, p. 292.

43 Max Müller, Lectures on the Science of Language, Vol. 1, London, Longman Green, Longman and Roberts, 1861, pp. 21-22.

44 Hans Aarsleff, From Locke to Saussure: Essays on the Study of Language and Intellectual History, Minneapolis, University of Minnesota Press, 1982, p. 32.

45 Holger Pedersen, The Discovery of Language, Bloomington, Indiana University Press, 1931, p. 19.

46 Max Müller, Lectures on the Science of Language, Vol. 1, London, Longman Green, Longman and Roberts, 1861, p. 118.

47 Ibid.

48 Heinrich Meier, The Lesson of Carl Schmitt: Four Chapters on the Distinction between Political Theology and Political Philosophy, translated by Marcus Brainard, Chicago, University of Chicago Press, 1998, p. 60.

49 Paul Rabinow, French Modern, Cambridge, MIT Press, 1989, p. 8.

50 Raymond Schwab, The Oriental Renaissance: Europe's Rediscovery of India and the East, 1680-1880, translated by Gene Patterson-Black and Victor Reinking, New York, Columbia University Press, 1986, p. 24.

51 A. Abdel-Malek, Idéologie et renaissance nationale : l'Égypte moderne, 2e édition, Paris, Anthropos, 1969, pp. 189-198.

Martin Bernal, The Fabrication of Ancient Greece, 1785-1985, Vol. 1 of Black Athena: The Afroasiatic Roots of Classical Civilization. New Brunswick, NJ, Rutgers University Press, 1987, p. 269.

52 Hugo Friedrich, "On the Art of Translation", Translated by Rainer Schulte and John Biguenet, in Schulte and Biguenet (dir.), Theories of Translation: An Anthology of Essays from Dryden to Derrida, 1992, pp. 12-13.

53 Rainer Schulte and John Biguenet (dir.), Theories of Translation: An Anthology of Essays from Dryden to Derrida,Chicago, University of Chicago Press, 1992, p. 3.

54 Timothy Mitchell, Colonizing Egypt, New York, Cambridge University Press, 1988, p. 141.

55 Karl Marx, Capital, Vol. 1, London, Penguin, 1976, p 899.

56 V. N. Voloshinov, Marxism and the Philosophy of Language, Cambridge, Cambridge University Press, 1973, p. 84 and p. 94.

57 Ibid., p. 87.

58 Ibid., p. 72.

59 Ibid., p. 3.

60 Raymond Schwab, The Oriental Renaissance: Europe's Rediscovery of India and the East, 1680-188o, translated by Gene Patterson-Black and Victor Reinking, New York, Columbia University Press, 1986, p. 88.

61 Michel Foucault, The Order of Things: An Archaeology of the Human Sciences,New York, Vintage, 1970, p. 298.

62 Vicente L. Rafael, "The Cultures of Area Studies in the United States”, Social Text, $\mathrm{n}^{\circ} 41,1994$, p. 91.

Dipesh Chakrabarty, "Reconstructing Liberalism? Notes toward a Conversation between Area Studies and Diasporic Studies”, Public Culture, nº10, 1998, pp. 457-481.

63 Tani E. Barlow, “Colonialism's Career in Postwar China Studies”, Positions, vol. I, 1993, pp. 224-67.

64 Ye Bingnan, It Is Said That in Zhejiang: A Selection of Literary and Historical Documents from Zhejiang, Vol. 54, Editorial Board of the Zhejiang Provincial Political Consultative Conference, literary and historical materials, Zhejiang, Zhejiang People's Publishing House, 1993, p. 23. 
65 Michel de Certeau, The Writing of History, Translated by Tom Conley, New York, Columbia University Press, 1988, pp. xxv-xxvii.

66 Susan Buck-Morss, The Dialects of Seeing:Walter Benjamin and the Arcades Project, Cambridge, MIT Press, 1991, p. 131.

67 Roland Barthes, "Eiffel Tower", in Susan Sontag (dir.), A Barthes Reader, New York, Hill and Wang, 1983, p. 236.

68 Sigfried Giedion, Bauen in Frankreich: Eisen, Eisenbeton, Leipzig, Klinkhardt and Biermann, 1926, p. 7.

Walter Benjamin, "N [Theoretics of Knowledge; Theory of Progress]", Philosophical Forum, n ${ }^{\circ} 15,1983-1984$, p. 3.

69 Susan Buck-Morss, The Dialects of Seeing:Walter Benjamin and the Arcades Project, Cambridge, MIT Press, 1991, p. 130.

70 Ibid., p. 134 .

71 Umberto Eco, The Search for the Perfect Language, Translated by James Fentress, Oxford, Blackwell, 1995, p. 209.

72 Donald P., Green and Ian Shapiro, Pathologies of Rational Choice Theory: A Critique of Applications in Political Science, New Haven, CT, Yale University Press, 1994, p. 195.

73 Joseph V. Brogan, “A Mirror of Enlightenment: Rational Choice Debates”, Review of Politics, ${ }^{\circ} 58,1996$, pp. 793-806.

74 Mechrhild Leutner, "Politik undWissenschaft: Die Marginalisierung nichtphilologischer Ansätze und die Konstruktion der Sinologie als Philologie”, Berliner China-Hefte, $\mathrm{n}^{\circ} 20,2001$, pp. 7-30.

75 Pierre Ryckmans (Simon Leys), "Orientalism and Sinology", ASAA Review (Australian Asian Studies Association), April 1983-April 1984, p. 20.

76 Vicente L. Rafael, "The Cultures of Area Studies in the United States", Social Text, $\mathrm{n}^{\circ} 41,1994$, p. 91.

77 Benjamin A. Elman, From Philosophy to Philology: Intellectual and Social Aspects of Change in Late Imperial China, Cambridge, Council on East Asian Studies, Harvard University, 1984.

78 Rosalind Coward and Ellis John, Language and Materialism: Developments in Semiology and the Theory of the Subject, London, RKP, 1977.

79 Hans Aarsleff, From Locke to Saussure: Essays on the Study of Language and Intellectual History, Minneapolis, University of Minnesota Press, 1982, p. 281.

80 Ibid., pp. 42-83.

81 Ibid., p. 22.

82 Louis Marin, Food for Thought, translated by Mette Hjort, Baltimore, MD, Johns Hopkins University Press, 1989, p. 4.

83 Hugo Friedrich, "On the Art of Translation", Translated by Rainer Schulte and John Biguenet, in Schulte and Biguenet (dir.), Theories of Translation: An Anthology of Essays from Dryden to Derrida, 1992, pp. 12-13.

84 Max Müller, Lectures on the Science of Language, Vol. 1, London, Longman Green, Longman and Roberts, 1861, p. 123.

85 George A. Kennedy, The Selected Works of George A. Kennedy, New Haven, CT, Yale University Press, 1965, p. 104.

86 Umberto Eco, The Search for the Perfect Language, Translated by James Fentress, Oxford, Blackwell, 1995, pp. 114-115.

87 Max Müller, Lectures on the Science of Language, Vol. 1, London, Longman Green, Longman and Roberts, 1861, p. 162.

88 Ibid., pp. 156-157.

89 Ibid., p. 158.

90 V. N. Voloshinov, Marxism and the Philosophy of Language, Cambridge, Cambridge University Press, 1973, p. 14. 
91 Max Müller, Ibid., p. 14.

92 Michel Foucault, The Order of Things: An Archaeology of the Human Sciences,New York, Vintage, 1970, pp. 296-297.

93 Raymond Schwab, The Oriental Renaissance: Europe's Rediscovery of India and the East, 1680-188o, translated by Gene Patterson-Black and Victor Reinking, New York, Columbia University Press, 1986.

94 Lewis A. Maverick, China: A Model for Europe, San Antonio, TX, Paul Anderson, 1946.

95 Lawrence Venuti, The Translator's Invisibility: A History of Translation, London, Routledge, 1995 .

96 Paul Cohen, Discovering History in China, New York, Columbia University Press, 1984, pp. 196-197.

97 Louis Marin, Food for Thought, translated by Mette Hjort, Baltimore, MD, Johns Hopkins University Press, 1989, pp. 12-14.

98 Sigmund Freud, The Basic Writings of Sigmund Freud, Translated and edited by A. A. Brill, New York, Random House, 1966, p. 191.

99 Slavoj Žižek, The Sublime Object of Ideology, London, Verso, 1989, p.11.

100 I. R. Titunik, "The Formal Method and the Sociological Method (M. M. Bahktin, P. N. Medvedev, V. N. Voloshinov) in Russian Theory and Study of Literature", in V. N. Voloshinov, Marxism and the Philosophy of Language, Cambridge, Cambridge University Press, 1973, p. 191.

101 Mixail Baxtin [Mikhail Bakhtin], "Discourse Typology in Prose", in Ladislav Matejka and Krystyna Pomorska (dir.), Readings in Russian Poetics: Formalist and Structuralist Views, Cambridge, MIT Press, 1971, pp. 196-198.

102 V. N. Voloshinov, Marxism and the Philosophy of Language, Cambridge, Cambridge University Press, 1973.

103 Bernard S. Cohn, "The Command of Language and the Language of Command", in Ranajit Guha (dir.), Subaltern Studies IV: Writings on South Asian History and Society, Oxford, Oxford University Press, 1985.

104 Stephen Stigler, The History of Statistics: Measurement of Uncertainty before 1900, Cambridge, Belknap Press of Harvard University Press, 1986, p. 95.

105 Bruno Latour, We Have Never Been Modern, translated by Catherine Porter, Cambridge, Harvard University Press, 1993, p. 18 and p. 35.

106 Stephen Stigler, Ibid., pp. 265-266.

107 Library of Congress, Library of Congress Asian Collections: An Illustrated Guide, Washington, DC, Library of Congress, 2000, p. 13, p. 32 and p. 46.

108 Dipesh Chakrabarty, "Reconstructing Liberalism? Notes toward a Conversation between Area Studies and Diasporic Studies”, Public Culture, nº10, 1998, pp. 457-481.

109 Julian H. Stewart, Area Research: Theory and Practice, New York, SSRC, 1950, p. xi.

110 Tani E. Barlow, “Colonialism's Career in Postwar China Studies”, Positions, vol. I, 1993, pp. 224-267.

111 Ramon H. Myers and Thomas A. Metzer, "Sinological Shadows: The State of Modern China Studies in the U.S.", Australian Journal of Chinese Affairs, nº 4 , 1980, pp. 1-34.

112 Chalmers Johnson, “What's Wrong with Chinese Political Studies”, Asian Survey, October, 1982, pp. 919-933.

\section{Pour citer cet article}

Référence électronique

Michael DUTTON, « Lead Us Not into Translation: Notes Toward a Theoretical Foundation for Asian Studies », Transtext(e)s Transcultures 跨文本跨文化 [En ligne], 7 | 2012, mis en ligne le 02 décembre 2012, consulté le 24 avril 2013. URL : 


\section{Auteur}

\section{Michael DUTTON}

MICHAEL DUTTON is Professor in the Department of Politics, Goldsmiths College, University of London and formerly Professor of Political Cultures at the Griffith Asia Institute, Griffith University. Professor Dutton's research is characterized by a strong interest in contemporary social and cultural theory wed to a specific 'archive' called China. This has led to a range of rather disparate set of issues that quite often move his work out of the specifics of China. His current interests include an investigation of the politics of the gift, a study of the friend/enemy distinction, and an appreciation of the importance of everyday life in the flow of politics.

MICHAEL DUTTON est Professeur au sein du Département de science politique de Goldsmiths College de l'Université de Londres, anciennement Professeur de cultures politiques au Griffith Asia Institute à l'Université Griffith. Ses recherches sont caractérisées par un fort intérêt pour la théorie sociale et culturelle contemporaine ainsi que pour une 'archive' particulière dénommée Chine. Ceci l'a mené à l'étude d'un éventail de questions diverses qui ont souvent déplacé son travail en dehors du cas précis de la Chine. Ses intérêts actuels portent sur les politiques du don, la distinction ami/ennemi, et l'importance de la vie quotidienne dans le flux politique.

\section{Droits d'auteur}

(C) Tous droits réservés 